DOI 10.21867/KjK/2016.1.10.

\title{
A VÍZHEZ VALÓ JOG ÉS A MAGYAR VÍZIKÖZMÜ-SZOLGÁLTATÁSOK•
}

\author{
Szilágyi János Ede
}

A tanulmány a vízhez való jog magyarországi érvényesülésével foglalkozik, és - a korábban már felvetett kérdésekhez kapcsolódva ${ }^{2}$-alapvetően megtörtént ügyek kapcsán érinti a kérdést, elsődlegesen a víziközmü-szolgáltatásokra koncentrálva.

Világviszonylatban Magyarország az ivóvíz-szolgáltatás elterjedésében nem áll rosszul, és hasonló következtetés fogalmazható meg a szennyvízágazat vonatkozásában is. A képet némileg árnyalja viszont, hogy a két víziközmü-alágazat közül az ivóvíz-szolgáltatás jelentősen jobban áll. Az is vitathatatlan, hogy mind a korábbi, mind pedig a 2014-ben kezdődött európai uniós költségvetési időszakban Magyarország jelentős pénzeket hívott le ${ }^{3}$, illetve tervez lehívni annak érdekében, hogy a rendelkezésre álló víziközmü-infrastruktúrát fejlessze illetve bővítse. Mindez egyértelmủen segítette, illetve segítheti a vízhez való jog érvényesülését a víziközmü-szolgáltatások területén. Fontosnak tartom megjegyezni azt is, hogy a lakosság száz százalékos elérése a víziközmü-szolgáltatások által technikai-pénzügyi okokból nem lehet cél, hiszen minden egyes felhasználó rendszerbe kapcsolása (gondoljunk például a távoli tanyákon, szétszórtan élő polgártársainkra) egész egyszerüen gazdaságtalan és célszerütlen lenne, és ezt a vízhez való jog különböző dokumentumai sem fogalmazzák meg standardként. Ilyen természetszerüen kívülálló személyek vonatkozásában a vízhez való jog más módon is biztosítható.

Ezen kiindulási pont rögzítése mellett mindazonáltal vizsgálható, és megítélésem szerint vizsgálandó is az, hogy marad-e még fejleszteni való a víziközmü-szolgáltatások és a vízhez való jog viszonylatában, vagy pedig a helyzet immáron a tökéleteshez közelít.

E kérdés tárgyában szervezett megbeszélést - konkrétan az ENSZ Víz és Egészség Jegyzőkönyvének magyarországi érvényesülése tárgyában - az Alapvető Jogok Biztosa (AJB) 2015. június 2. napján. A jog érvényesülése kapcsán a hozzászólók számos, víziközmüszakpolitikát is érintő megállapítást tettek. Pump Judit előadásában, illetve hozzászólásában kitért arra, hogy az AJB (illetőleg jogelődjei) de facto már régóta eljárnak a vízhez való jog érvényre jutása érdekében, azonban ezt de iure más alapjogokra hivatkozással teszik. Külön kiemelte a megfizethetőség és a díjak kérdését, a tisztességes eljáráshoz való jogot. Kitért rá, hogy a rendszerváltást követő privatizációs folyamatok számos rendezetlen ügyet hagytak hátra; számos vízhasználat például szivességi használatként élt tovább; a locsolási rendszerek (mint adott esetben a felhasználók és a víziközmü-szolgáltatók közötti közvetítő rendszerek) átalakítása nehézkes. Fórika László előadásában beszélt arról, hogy a zártkerteken kialakult szegény-negyedek kifejezetten rossz helyzetben vannak, hiszen e zártkertek kapcsán az

\footnotetext{
A tanulmány a Magyar Tudományos Akadémia és a Debreceni Egyetem Állam- és Jogtudományi Kar közös, MTA-DE Közszolgáltatási Kutatócsoportjának a Területi közszolgáltatások szabályozásai címủ projektje keretében készült. A projekt leírására 1.: Horváth M.T.: Szempontok a területi közszolgáltatások regulációs változásainak vizsgálatához. In: HMT (szerk.): Kilengések. Közszolgáltatási változások. Budapest: Dialóg Campus, 2013. 9-25. old.

${ }^{1}$ Szilágyi János Ede, egyetemi docens, ME-ÁJK

${ }^{2}$ Ld. Szilágyi János Ede: Víziközmü-szolgáltatás és a vízhez való jog érvényesülése Magyarországon. In: Közjavak, I. évf. 2015/2. szám. október-december. 42-45.

${ }_{3}$ http://www.kormany.hu/hu/nemzeti-fejlesztesi-miniszterium/parlamenti-allamtitkarsag/hirek/tobb-mintezermilliard-forint-jut-kornyezeti-es-energiahatekonysagi-fejlesztesekre (letöltés: 2015. november 1.)
} 
önkormányzatoknak kevés kötelezettsége van a vezetékes víz biztosítására. Nagy Edit, a Víziközmü Szövetség képviselöjeként problémaként jelölte meg azt, hogy csak az Alföldön évente egy településnyi fogyasztó kerül kizárásra, akik többsége nem is kerül vissza a rendszerre. Márpedig - emelte ki - ez a víziközmű rendszerek gazdaságos működése szempontjából óriási nehézség; hasonlóan az ágazatot érintő rezsicsökkentéssel és a közmüadóval. Mindezekre tekintettel az új díjrendszer kialakítása kapcsán - a vízhez való jog megfizethetőségét érintve - elképzelhetőnek tartana egy sávos díjképzést, amelynél a legalacsonyabb sávban nulla forintos lenne a szolgáltatás díja. A konferencián felvetődött egy pénzügyi alap önkormányzatok, állam, szolgáltatók általi létrehozásának gondolata a nemfizetők számára; továbbá felvetődött az is, hogy a megfizethetőség szempontjából talán nem is annyira a szolgáltatás díj megfizethetösége jelent problémát, hanem a víziközmühöz történő csatlakozás rákötési díja, ezért lehet, hogy inkább a rákötést kellene szociálisan támogatni.

A megbeszélésen szóba került több ügy is. ${ }^{4}$ Alább a nagyobb sajtóvisszhangot kiváltó lyukóvölgyi illetve az ózdi jelentéseket emelem csak ki ezek közül.

Lyukóvölgy Miskolc külterületén található. A rendszerváltást megelőzően a miskolciak kedvelt hétvégi pihenőhelye volt, ahol kertjeiket müvelve töltötték szabadidejüket a város lakói. Ezt követően - a legkülönbözöbb okok miatt - fokozatosan vált jelentős részben romák által lakott szegregátummá. A szegregátumban élők közül sokan nem fizettek megfelelően a víziközmü-szolgáltatásért, ezért a szolgáltatásban - s ez adja az ügy egyik jogi szempontból is érdekes specialitását - közvetítőként résztvevő, s a nem fizetés miatt számos hátrányt szenvedő kertszövetkezet 2013 tavaszának végén elzárta a vizet a felhasználók elől. A vízelzárás-problémakörét némileg árnyalta még az is, hogy a helyi politika is aktuálpolitikai üggyé tette azt. Ezt követően mind az $\mathrm{AJB}^{5}$, mind pedig Miskolc város vezetése is közvetíteni igyekezett az ügyben. Témánk szempontjából tehát az ügyben a nehézséget az jelentette, hogy a Vksztv. ${ }^{6}$ korábban hivatkozott, vízhez való joggal összefüggésbe hozható rendelkezései, a víziközmü-szolgáltatásban közvetítői szerepkörben bekapcsolódó szereplö miatt nehezen voltak érvényesíthetők.

Az AJB 5527/2013. számú ózdi ügye immáron expressis verbis foglalkozik magával az „egészséges ivóvízhez való joggal” (sőt az AJB meg is állapította, hogy az önkormányzati döntés ,sértette az egészséghez és az egészséges ivóvizhez való alapvető emberi jogot”), de nem a klasszikus értelemben vett - vagyis a felhasználó és a víziközmü-szolgáltató között közvetlen szerződéses viszonyon alapuló - víziközmü-szolgáltatások vonatkozásában, hanem annak speciális esete, a közkifolyók müködtetése kapcsán.

2013 nyarán az ózdi képviselö-testület döntése alapján több utcában is korlátozták a közterületen található közkifolyók vízhozamát, illetve lezárták azokat. A lyukóvölgyi ügyhöz hasonlóan egyébiránt itt is jelentős számban voltak érintve roma lakosok, és az ügy itt is jelentősen átpolitizálódott. Az ügy víziközmü-szolgáltatásokkal összefüggésbe hozható lényeges elemei - több más mellett - a következők:

ad 1, Az AJB foglalkozott a közkifolyós vízszolgáltatás speciális jogi jellegével. A Vksztv végrehajtására kiadott 58/2013. kormányrendelet értelmében a közkifolyókon szolgáltatott ivóvizet - háztartási célú vízhasználatra - a közmüves ivóvízellátásba be nem kötött vagy ivóvíz-szolgáltatás korlátozással érintett ingatlan lakói vehetik rendszeresen igénybe. Az AJB

\footnotetext{
${ }_{5}^{4}$ Például. az ivóvízhez való hozzáférés gyermekjogi aspektusait vizsgáló AJB-677/2013. számú jelentés. http://www.ajbh.hu/-/veszelyhelyzetet-jelent-a-vizhiany-az-ombudsman-a-lyukovolgyi-vizvezetekatvagasarol?redirect=http\%3A\%2F\%2Fwww.ajbh.hu\%2Fkezdolap\%3Fp p id\%3D3\%26p p lifecycle\%3D0\%2 $6 p$ p state\%3Dmaximized\%26p p mode\%3Dview\%26 3 groupId\%3D0\%26 3 keywords (letöltés: 2015. november 1.)

${ }^{6}$ 2011. évi CCIX. törvény a víziközmü-szolgáltatásról
} 
mindezek kapcsán akként értelmezte a vonatkozó rendelkezéseket, hogy: „a közkifolyók esetén az önkormányzat minösül fogyasztónak, és kizárólag az önkormányzat és a szolgáltató áll egymással közüzemi jogviszonyban. Közkifolyó esetében nem köt a szolgáltató külön-külön közüzemi szerzödést a közkifolyóról vizet vételezö lakossággal".

ad 2, Az AJB megállapította, hogy az ivóvízhez való jog több módon is megvalósítható, az ivóvízhez való hozzáférés víziközmü-szolgáltatáson keresztül történő biztosítása, csak az egyik esetköre ennek: „az ivóvízhez való eljutás meghatározott módja nem alapjog”.

ad 3, A fenti gondolatmenet folytatásaként, lényegében a vízhez való jog hozzáférhetősége tárgyában az AJB ugyanakkor hozzáteszi, hogy ott, ,ahol vezetékes vízhálózat van kiépítve, ott az önkormányzat elsödlegesen a max. 150 méterenként elhelyezett közkifolyók müködtetésével köteles a min. 20 liter/fö/napra vonatkozó (közegészségügyi) vízbiztositási feladatait ellátni." Mindezek kapcsán megjegyzem, hogy a Vksztv egyik 2015-ös módosítása az ivóvizet kizárólag a közkifolyókról vételező természetes személyek esetén ezen 150 méteres távolságot immáron nagyobb, 300 méteres standardra módosította (ami lényegében felfogható egyfajta visszalépésként is...).

ad 4, Az ózdi ügyben - a magyarországi átlagfogyasztásra illetve a napi hőmérséklet évszakonkénti jelentős eltérésére is figyelemmel - az AJB elemezte Vksztv-ben is szereplő napi 20 liter/fö vízfogyasztási limitet. Többek között azért is, mert az ózdi ügyben előadott egyik panaszos kifogásolta, hogy ,a kánikulára tekintettel - ... az ózdi önkormányzat által biztositott - 150 méteren belül elérhetö napi 20 liter víz nem elégséges az alapvetö szükségletek biztositásához”. Ennek kapcsán az AJB megfogalmazta, hogy „megfontolást érdemel, hogy a közegészségügyi vízigény biztositására vonatkozó egységes szabályozást nem kellene-e a vizigény jól modellezhetö idöszakos ingadozáshoz igazitani, azaz a nyári időszakban min. 30\%-kal megemelni a 20 literes tételt".

ad 5, Az ózdi ügyben fontos kérdésként fogalmazódott meg, hogy vajon a közkifolyós vízvételezés költségei átháríthatók-e a felhasználókra. Az 58/2013. kormányrendelet korábbi normaszövege lehetőséget adott arra, hogy jogszabályban ezt az önkormányzat megtegye. Az AJB az ügy idején hatályos normaszöveg értelmezésekor erre tekintettel megállapította, hogy „,mivel az önkormányzati rendelet is jogszabály, a közkifolyók esetében a fogyasztási díjat az önkormányzat „vízhasználati dijként” ráterhelheti a lakosokra.” Egyébiránt az ózdi ügyben az önkormányzat 6/1997. önkormányzati rendelete alapján ,a víziközmü-szolgáltatónak a közkifolyós vízvételezési módra is szerzödést kellett volna kötnie a fogyasztókkal (akik számára átalányszámlázást végeztek volna) - azonban ez a gyakorlatban nem történt meg." Fontos megjegyezni, hogy az 58/2013. kormányrendelet egy 2014-es módosítása ezt a „díjfizetés ráterhelési-klauzulát” immáron törölte a kormányrendelet szövegéböl; ami felfogható akként is, hogy ezen jogszabály-módosítással előrelépés történt a vízhez való jog érvényesülése tárgyában.

Az AJBH konferenciáját követően újabb, vízszolgáltatást is érintő ügy vált ismertté. Az AJB 1474/2014. számú, miskolci telep-felszámolási ügyében a vízhez való jog vonatkozásában leginkább a diszkriminációmentes vízhez való hozzáférés kérdése érdemel kiemelést, nem véletlen, hogy civilek kezdeményezésére ezért foglalkozott az üggyel - mások mellett - az Egyenlő Bánásmód Hatósága is. Az ügyben egyébiránt több helyen is elemezhető a vízhez való hozzáférés; így például a vizsgálat egyik tárgyát képező önkormányzati rendeletben (amely az életvitelszerü lakhatásra alkalmas ingatlan fogalmánál fogalmaz meg vízhez kötődő elvárásokat), vagy éppen a razzia-szerüen végrehajtott hatósági-közmüszolgáltatói eljárás diszkriminációs vonatkozású vizsgálata során.

A fentiekre tekintettel úgy gondolom, hogy a vízhez való jog kérdése aktuális marad az elkövetkező időszakban, mind nemzetközi, mind uniós, mind pedig hazai szinten. A fenti esetekből kétségtelennek tünik továbbá az is, hogy nem csak a jog szabályozása, de a vízhez való jog XXI. századi érvényesülésében is akad még bőven tennivalónk. 